\author{
ОСОБЛИВОСТІ РОЗВИТКУ ТЕОРІЇ УПРАВЛІННЯ ЗАКЛАДАМИ \\ ВИЩОЇ ОСВІТИ В УКРАЇНІ ОСТАННЬОÏ ЧВЕРТІ XX СТОЛІТТЯ
}

\title{
FEATURES OF HIGHER EDUCATION INSTITUTIONS' MANAGEMENT THEORY DEVELOPMENT IN UKRAINE OF THE LAST QUARTER OF THE XX CENTURY
}

УДК 371.2

DOI https://doi.org/10.32843/2663-

6085.2019.12-2.17

\section{Васиньова Н.С.,}

асистент кафедри публічної служби

та управління навчальними

й соціальними закладами

Навчально-наукового інституту

публічного управління, адміністрування

та післядипломної освіти

ДЗ «Луганський національний

університет імені Тараса Шевченка»

\begin{abstract}
у статті на основі проведення історикопедагогічного аналізу наукових праць останньої чверті XX століття охарактеризовано чинники, які вплинули на зародження теоретико-методологічних засад управління закладами вищої освіти в Україні; з'ясовано внесок радянських учених у розвиток теорії управління освітніми закладами; визначено особливості історії розвитку теорії управління закладами вищої освіти в Україні останньої чверті XX століття. В основу методики вивчення наукових джерел покладено ідею багатогранного, всебічного огляду предмета дослідження. у статті авторка спирається на такі методи дослідження, як: аналіз, синтез, контент-аналіз, узагальнення та систематизація отриманих фрактів.

Ключові слова: теорія управління, вищі навчальні заклади, заклади вищої освіти, розвиток теорії управління, особливості розвитку теорії управління.
\end{abstract}

В статье на основе проведённого историкопедагогического анализа научных изданий последней четверти XX века охарактеризованы фракторы, которые повлияли на зарождение теоретико-методологических принципов управления высшими учебными заведениями в Украине; определен вклад советских учёных в развитие теории управления образовательными заведениями; выяснены особенности истории развития теории управления высшими учебными заведениями в Украине последней чет- верти XX века. В основу методики изучения научных источников положено идею многогранного, всестороннего обзора предмета исследования. В статье автор опирается на такие методы исследования, как: анализ, синтез, контент-анализ, обобщение и систематизация полученных срактов.

Ключевые слова: теория управления, высшие учебные заведения, заведения высшего образования, развитие теории управления, особенности развития теории управления.

Factors that influenced the emergence of the theoretical and methodological principles of the higher educational institutions' management theory in Ukraine have been characterized in the article on the basis of the historical and pedagogical analysis of the scientific works of the last quarter of the XX century; the contribution of Soviet scientists to the development of the higher educational institutions' management theory has been determined; the peculiarities of the history of the higher educational institutions' management theory in Ukraine in the last quarter of the $X X$ century have been determined. The method of scientific sources studying has been based on the idea of a multi-faceted, comprehensive examination of the researched subject. In the article, the author relies on such research methods as analysis, synthesis, content analysis, generalization and systematization of the facts.

Key words: management theory, higher educational institutions, institutions of higher education, management theory development, peculiarities of the management theory development.
Постановка проблеми. Проблема розвитку теорії управління закладами вищої освіти в Україні стає особливо актуальною в умовах чинної масштабної ресрорми і у ссрері вищої освіти, і в системі управління нею, оскільки дає змогу відстежити основні тенденції й особливості розвитку теорії управління закладами вищої освіти та визначити рівень вивченості цих питань.

Аналіз останніх досліджень і публікацій. Основні засади редорми закладені новим Законом України «Про вищу освіту» [15] та Стратегією ресрормування вищої освіти в Україні до 2020 року [14].

Серед праць, які мали значний вплив на зародження теоретико-методичних засад управління освітніми закладами, варто назвати наукові доробки В. Бондаря, П. Дробязко, В. Жука, В. Маслова, Б. Мирончика, Н. Суховєєвої, В. Сухомлинського, П. Худомінського, М. Черпінського, Р. Шакурова, які розглядають науково-педагогічну діяльність учителів, управління навчально-виховним процесом, упровадження передового досвіду, удосконалення діяльності вчителів і директорів шкіл, організаційно-управлінський аспект у педагогічній діяльності тощо. У наукових дослідженнях проблему розвитку теорії управління закладами вищої освіти в ті часи майже не розглядали, що зумовлює актуальність зазначеної проблеми.

Водночас нові вимоги до якості вищої освіти, управлінської діяльності у сфрері освіти, потреби в ефрективних шляхах досягнення якості діяльності освітніх закладів спонукають до ґрунтовного аналізу напрацювань радянських учених, що $є$ перспективним вектором активного розвитку теорії і практики управління закладами вищої освіти в Україні.

Мета статті полягає у вивченні логіки становлення теорії управління в освітніх системах та визначення внеску радянських учених у розвиток теорії управління закладами вищої освіти. 
Виклад основного матеріалу дослідження. Для ґрунтовного дослідження розвитку теорії управління закладами вищої освіти в Україні останньої чверті XX століття здійснено змістовний аналіз джерел цього часу, проведено семантичний та контент-аналіз тематик публікацій, дисертацій для визначення кількісних і якісних показників уживання управлінських понять 3 подальшим установленням зв'язків між змістом текстів і тематик документів для з'ясування стану розвитку теорії управління зазначеного періоду.

Аналіз наукових джерел останньої чверті XX століття засвідчує, що в цей період було захищено 13 дисертацій вітчизняних авторів, майже всі дослідження спрямовані на аналіз науково-педагогічної діяльності вчителів, управління навчальновиховним процесом (П. Дробязко, Н. Суховєєва, В. Бегей, Б. Мирончик та ін.); упровадження передового досвіду, удосконалення діяльності вчителів і директорів шкіл (В. Жук, В. Маслов); М. Черпінський розглядає організаційно-управлінський аспект у педагогічній діяльності тощо.

у цей проміжок часу відсутні дисертаційні роботи з питань управління закладами вищої освіти. Установлено, що в 76-80-ті рр. переважають індивідуальні наукові розвідки проблем теорії управління вищими навчальними закладами. Відсутні колективні дослідження, участь у яких можуть брати фрахівці різного наукового спрямування та викладачі ЗВО.

Опубліковано 39 книжок (посібників, методичних рекомендацій), з них одна присвячена питанням організації системи контролю якості освіти у вищих навчальних закладах [11]; 35 статей, з них тільки шість стосуються вищої освіти та окремих питань управління ВН3 [6; 7; 9; 12; 23].

Для з'ясування головних питань, які розглядають учені останньої чверті XX століття в Україні, було проведено аналіз назв основного масиву джерел з проблематики. Нами визначено рубрикатор для розгляду основних категорій розвитку теорії управління ВН3. Одиниця (категорія) аналізу становить смислове (ключове) висловлення в назві публікації, яке забезпечує його змістовну характеристику. Частота використання цих одиниць свідчить про значення, якого надавали педагоги, керівники, учені того часу тим чи тим управлінським проблемам у своїх дослідженнях.

Аналіз за розробленою методологією допоміг визначити напрям проведених досліджень та з'ясувати, на які питання спрямована теорія управління освітніми закладами в Україні останньої чверті XX століття.

Результати аналізу показують, що в 76-80-ті рр. фрахівці розглядають питання керівництва школою, зміст управлінської діяльності, управління підвищення кваліфікації вчителів, директорів шкіл, внутрішньошкільний контроль, фрункції управ- ління, систему управління, компетентність директора школи, аналізується досвід роботи вчителів і директорів шкіл.

Головну увагу приділено розробці методів і завданням, принципам і підходам до управління. Тематика публікацій здебільшого спрямована на вивчення внутрішньошкільного управління (М. Анжієвський [10], М. Сунцов [5], П. Зимін [4]); розробку методичних рекомендацій лекторам, керівникам загальноосвітніх шкіл, учителям (Є. Хриков [25], Г. Єльникова [19] та ін.). Судячи 3 назв видань, науковці також звертають увагу на психологічні аспекти управління освітою, визначення ролі психологічних знань сучасного керівника (О. Дейнеко) [8]; на організацію праці та особистість директора школи, що впливало на результативність його управлінської діяльності (В. Бондар, М. Черпінський, В. Сухомлинський, Н. Рентюк, Т. Фролов, [3; 16; 20-21; 24]); на діяльність молодого вчителя, аналіз уроку та проблему вдосконалення внутрішньошкільного керівництва й удосконалення контролю (О. Сай [18], В. Товарницький [23]). В. Литовченко розглядає питання керівництва в умовах кабінетної системи [13]). Зауважимо, що в деяких студіях висвітлено питання комплексного (А. Розенберг [17]) та ситуативного підходів (Ю. Табаков) до процесу управління [22]. Питання компетентності директора школи, розподілу обов'язків між директором та заступником, раціоналізації праці репрезентує $€$. Березняк [2].

Аналіз семантичного спектра назв джерел дає підстави зробити висновок, що кількість досліджень з проблематики значно низька. Відсутні дисертаційні праці з висвітлення проблем управлінської діяльності 3ВО.

У назвах праць переважають поняття «вдосконалення організаційно-педагогічної діяльності», «внутрішньошкільний контроль», «керівництво школою», «організаційно-управлінські ситуації», «розподіл управлінської праці», «раціональна праця», «педагогічне навантаження», «оптимізація внутрішньошкільного контролю», «система», «система роботи вчителя», «навчально-виховний процес». Найбільш поширеними поняттями цього часу $є$ : «контроль» та «інспектування», у публікаціях майже не розглядалися принципи й закони демократизації, гуманізації тощо.

Пізніше з'являються та поширюються поняття «здоровий мікроклімат», «комплексне планування», «управлінська ситуація», «система оцінки», «система управління», «удосконалення управління», «педагогічна рада», «процес управління», «планування роботи», «стиль керівництва (управління)», «самоосвіта», «методи управління», «обов'язки».

Отже, учені розглянули коло всіх головних питань змісту управлінської діяльності, але 
загальноосвітнього навчального закладу. Так, аналіз тематики та змісту робіт призводить до висновку, що в цей період питання внутрішньошкільного контролю $є$ важливим складником управлінської діяльності. Однією з особливостей цього етапу є формування понятійного апарату внутрішньошкільного управління, більшість із перелічених понять використовується в практиці та теорії управління школою.

Водночас для з'ясування сутності уявлень педагогів, керівників, учених 76-80-х рр. XX століття про зміст управлінської діяльності та визначення актуальних питань теорії управління проведено аналіз тогочасних наукових праць. Аналіз робіт 76-80-х рр. XX ст. за зазначеною структурою подано в таблиці 1.

Остання чверть XX століття представлена здебільшого описовими працями. Фахівцями цього етапу було розглянуто коло більшості питань змісту управлінської діяльності загальноосвітнього закладу.

Розвиток теорії управління вищими навчальними закладами в Україні в цей період був тісно пов'язаний з розвитком педагогічної теорії і теорією управління школою. Цей період характеризується: узагальненням досвіду управлінської діяльності керівників шкіл у посібниках зі школознавства.

Також характерною рисою цих років був екстенсивний шлях розвитку теорії управління закладами освіти в Україні - збільшення кількості науковців, наукових праць і локальних досліджень. У цей період розпочалася переорієнтація робіт учених 3 опису й узагальнення окремого практичного досвіду на глибоке теоретичне обґрунтування тих чи тих аспектів теорії внутрішньошкільного управління та їхню експериментальну перевірку [1, с. 217-218].

Тобто в українській науці працювала достатня кількість учених, які своїми науковими доробками забезпечували теоретичне обґрунтування та практичне фрункціонування управління школою. У цей час збільшилась кількість досліджень і публікацій теоретичного спрямування. Усе це створювало умови для накопичення та узагальнення наукової інформації, але було пов'язано 3 кількісним, а не якісним збільшенням наукових розвідок 3 теорії управління освітніми закладами [Там само, с. 221]; досліджень з проблем управління закладами вищої освіти в Україні.

Аналіз тематик та змісту наукових розвідок 76-80-х рр. XX століття дав змогу дійти висно-

Таблиця 1

Аналіз робіт учених, присвячених вищій освіті та різним аспектам теорії управління ВН3 у 76-80-ті роки XX століття

\begin{tabular}{|c|c|c|c|c|c|c|c|c|c|}
\hline № 3/ח & Автори & 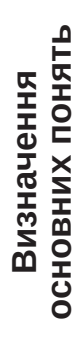 & 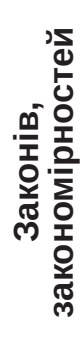 & 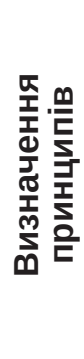 & 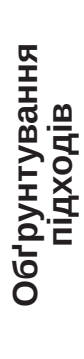 & 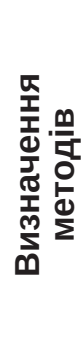 & 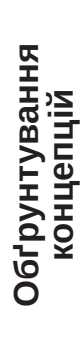 & 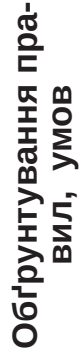 & 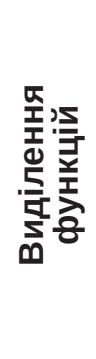 \\
\hline 1. & В. Бондар & + & - & + & - & + & - & + & + \\
\hline 2. & Н. Бутенко & + & - & - & - & + & - & - & - \\
\hline 3. & Н. Киркач & - & - & - & - & - & - & - & - \\
\hline 4. & О. Можаєв & - & - & - & + & + & - & + & - \\
\hline 5. & В. Нуждін & - & - & - & + & + & - & - & - \\
\hline 6. & Т. Рахімов, А. Якиревич & - & - & - & - & + & - & - & + \\
\hline 7. & О. Скрипниченко & + & + & + & + & - & - & + & + \\
\hline 8. & Ю. Табаков & + & + & - & - & - & - & + & + \\
\hline 9. & К. Червінський & - & - & + & + & - & - & + & + \\
\hline 10. & В. Шевчук & - & - & + & - & + & - & - & - \\
\hline
\end{tabular}

* - в одній роботі могли висвітлювати кілька питань 
вку, що розвиток теорії внутрішньошкільного управління цього часу вплинув на зародження теоретичних засад управління вищими навчальними закладами, що дає підстави вважати цей час етапом зародження теоретико-методологічних засад управління закладами вищої освіти, оскільки напрацювання таких учених, як М. Анжієвський, В. Бондар, С. Вінник, О. Гончар, Ю. Табаков, Г. Єльникова, Є. Хриков та ін., забезпечили теоретичне обґрунтування та практичне фрункціонування управління школою. Їхні дослідження стали поштовхом до зародження теорії управління закладами вищої освіти в Україні.

Висновки. Проведений історико-теоретичний аналіз дає підстави зазначити, що провідну роль у встановленні теорії управління закладами вищої освіти в Україні відіграла теорія і практика внутрішньошкільного управління, основні концепції якої стали орієнтиром розвитку теорії управління ЗВО в майбутньому.

Проведений аналіз здійснено в межах теми наукової роботи «Розвиток теорії управління вищими навчальними закладами в Україні (остання чверть XX - початок XXI століття)», тому дослідження не вичерпує всієї різноманітності питань із проблематики. Актуальним та перспективним завданням подальших розвідок $€$ аналіз теорії управління закладами вищої освіти в Україні за такими етапами в умовах сьогодення.

\section{БІБЛІОГРАФІЧНИЙ СПИСОК:}

1. Адаменко О.В. Розвиток педагогічної науки в Україні в другій половині XX століття (1950-2000рр.) : дис. ... д-ра пед. наук : 13.00.01. Луганськ, 2006. 612 с.

2. Березняк Є.С. Керівництво роботою школи / Є.С. Березняк, М.В. Черпінський. Київ : Рад. шк., 1970. 262 c.

3. Бондар В.І. Вибір форм керівництва залежно від мети управління навчально-виховним процесом. Рад. шк. 1978. № 12. С. 80-85.

4. Бутенко Н.Ю. Вопросы развития интеграции высшей школы, науки и производства. Хозрасчет, фонансы и кредиты. 1987. Вып. 29. С. 56-60.

5. Вопросы внутришкольного управления : сб. ст. / под ред. Н.С. Сунцова. Москва : НИИ школ МП РСФСР, 1975. Вып. 1. 164 с.

6. Вінник С.І. Головний напрям у роботі райвно. Рад. Шк. 1976. № 1. С. 81-86.
7. Вінник С.I. Поліпшуючи стиль керівництва школою. Рад. шк. 1977. № 6. С. 101-104.

8. Дейнеко О.А. Психологические знания современному руководителю. Сов. педагогика. 1985. № 10. С. 129-131.

9. Захаренко О.А. 3 щоденника директора школи. Рад. Шк. 1987. № 5. С. 66-68.

10. Керівництво школою / упоряд. М.А. Анжієвський. Київ : Рад. шк., 1978. 118 с.

11. Капто Г.Ю. Деякі питання управління школою повного дня. Рад. шк. 1979. №6. С. 64-68.

12. Кривонос І.Ф. Роль шкільного інспектора у впровадженні педагогічних здобутків. Рад. шк. 1977. № 1. С. 95-99.

13. Литовченко В.П. Внутрішкільний контроль і керівництво в умовах кабінетної системи. Рад. шк. 1975. № 9. С. 63-68.

14. Національна стратегія розвитку освіти в Україні на 2012-2021 роки. URL: http://zakon2.rada.gov.ua/ laws/show/344/2013 (дата звернення: 14.02.18).

15. Про вищу освіту : Закон України від 01.07.2014 р. № 1556-VII. URL: http://zakon0.rada.gov. ua/ laws/show/1556-18 (дата звернення: 20.03.19).

16. Рентюк Н.К. Контроль директора за реалізацією виховних завдань. Рад. шк. 1982. № 4. С. 72-74.

17. Розенберг А.Я. Комплексний підхід у діяльності класного керівника. Київ : Т-во «Знання» УРСР, 1985. 47 с.

18. Сай О.А. Запорука успіху - чіткий і дійовий контроль. Рад. шк. 1980. № 8. С. 77-80.

19. Система управління якістю роботи педагогічного колективу : метод. рек. в допомогу лекторам, кер. загальноосвіт. шк., вчителям / уклад. Г.В. Єльникова. Харків : Б. в., 1989. 39 с.

20. Сухомлинський В.О. Директор школи керівник навчально-виховної роботи. Рад. шк. 1953. № 1. С. 38-42.

21. Сухомлинський В.О. Розмова 3 молодим директором. Київ : Рад. шк., 1988. 284 с.

22. Табаков Ю.Я. Про переваги ситуативного підходу до процесу внутрішкільного управління. Рад. шк. 1979. № 4. С. 76-79.

23. Товарницький В.І. Відвідування та аналіз уроку. Рад. Шк. 1982. № 9. С. 67-69.

24. Фролов П.П. Школа молодого директора. Москва : Просвещение, 1988. 224 с.

25. Хрыков Е.Н. Внутришкольный контроль за внеклассной и внешкольной работой по трудовому воспитанию : метод. рек. рук. шк. Ворошиловград : ВГПИ, 1982. 30 с. 